ENTREPRENEURSHIP AND SUSTAINABILITY ISSUES

ISSN 2345-0282 (online) http://jssidoi.org/jesi/

2020 Volume 7 Number 4 (June)

http://doi.org/10.9770/jesi.2020.7.4(27)

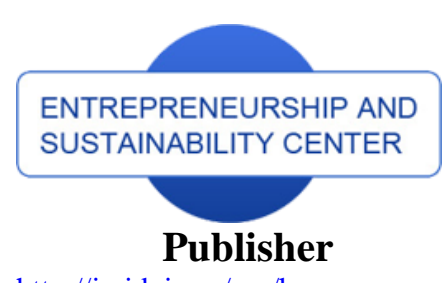

http://jssidoi.org/esc/home

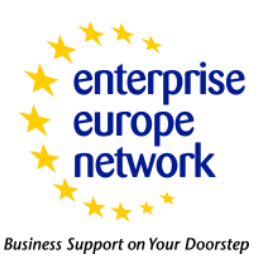

Business Support on Your Doorstep

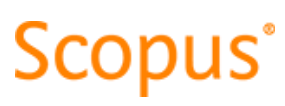

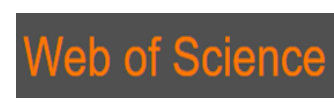

Clarivate
Analytics

\title{
SCORING METHOD AS APPLIED TO INNOVATION PROJECT EVALUATION FOR STARTUP SUPPORT
}

\author{
Ekaterina Y. Litau \\ Saint Petersburg National Research University of Information Technologies, Mechanics and Optics (ITMO University) \\ 49, Kronverkskiy pr., St. Petersburg, 197101, Russian Federation \\ E-mail: ekaterina-litau@yahoo.com
}

Received 18 November 2019; accepted 15 Mach 2020; published 30 June 2020

\begin{abstract}
In this paper, we present the scoring tool for startup evaluation called the MDP method (Management of Developing Projects) for an academic discussion. The MDP method implies the application of qualitative and quantitative criteria with due considerations given to personality types of main economic entities. The method's aims are better evaluation, better business development and support to participants of the innovation infrastructure. We believe that this method is set to become a cross-functional assessment tool that facilitates the successful development of investment and innovation projects. In time of the method piloting, we applied the consistent approach to testing including 12 in-depth interviews at the qualitative phase of the research. The following empirical study included the evaluation of innovation-based cases and projects in Russian business incubators. Findings showed that a number of promising projects (calculated by business incubators themselves) substantially differs from the number that we got owing to the piloted MDP scoring method. According to the MDP method, 9 of 17 projects are only promising, while the incubators themselves decided that 14 projects met eligibility criteria. At the same time, 3 startups out of 9 were successful at the selection stage, whereas they did not meet incubator selection criteria. Anyway, they were found promising within the framework of the MDP method. An important outcome of the MDP method's application is that in further monitoring of the most successful projects it will be possible to identify managerial skills of startup initiators by their personality type and this will consequently make it possible to develop university-based educational programs that meet the market demand.
\end{abstract}

Keywords: business incubator performance; innovation project; business incubator; startup selection criteria

Reference to this paper should be made as follows: Litau, E.Y. 2020. Scoring method as applied to innovation project evaluation for startup support. Entrepreneurship and Sustainability Issues, 7(4), 2978-2990. https://doi.org/10.9770/jesi.2020.7.4(27)

JEL Classifications: L26, O32

\section{Introduction}

Innovating is a focal point in the debate about economic issues. It is also a pressing issue in developed and developing economies. The concept of innovations has close associations with entrepreneurship and directly depends on the intensity of entrepreneurs' activism in economy (Toomsalu et al., 2019; Molina, Velilla \& Ortega, 2016; Dellis, Karkalakos \& Kottaridi, 2016; Lambert, 2018). Many national governments contribute to development of the system of measures to encourage entrepreneurship (Chernova, Degtereva, \& Zobov, 2016). They do this both in research and education, and by providing the direct support to startup owners. 


\section{ENTREPRENEURSHIP AND SUSTAINABILITY ISSUES}

ISSN 2345-0282 (online) http://jssidoi.org/jesi/

2020 Volume 7 Number 4 (June)

http://doi.org/10.9770/jesi.2020.7.4(27)

However, limited cost-efficiency of these measures has been a frequent issue in academic and public discussions, including in Russia (Yashin \&Kovrizhin, 2013; Rodionov, Tsypkin, \& Sinelnikova, 2012; Fourth annual... 2018). Birch discusses spendings of the USA taxpayers' funds for the support to unsustainable projects, as only 2-4 percent of them make a noticeable impact on national economy. The USA economist proposed the term gazelles to denote this group of enterprises. This term became frequent in the economic discourse and today refers to fastdeveloping dynamic companies (Birch, 1987; Birch \& Medoff, 1994).

In 2006, the Organization for Economic Cooperation and Development (OECD) provided the following standardized definition of gazelles, "All enterprises, the average annualized employment growth rate of which is over $20 \%$ over a three-year period and which have ten or more employees in the first year of observations." Birch thought that gazelles also included the companies that met the following criterion: at least $20 \%$ revenue growth annually over a specified interval. The category of gazelles supposedly includes young companies only, established not more than five years ago (Oslo Manual, 2010).

Business incubation is one of the tools within the entrepreneurship encouragement policy aimed at providing the comprehensive support to entrepreneurs at the early stage of their business. To join business incubators, projects go through selection procedures by competition. Project selection approaches mostly include calculations and formal criteria, conventional in terms of the financial analysis, while return on investment and strategic planning are not indicators of the entrepreneurial creativity (Baum \& Bird, 2010; Dimov, 2007; Baron, 2008; Batkovskiy et al., 2017). The application of quantitative criteria to the evaluation of important economic entities does not make it possible for us to understand personalities of initiators of such projects. It is clear that entrepreneurship is a specific type of the economic activity that requires a corresponding capability. This capability, entrepreneurial creativity, is decisive for the startup success. This brings into questions the efforts (made in the modern society) of influencing the enterprise development, as only a small number of projects has the potential for development.

The main goal of this research is to find evidences for the availability of the entrepreneurial capability and identify its criteria so that to justify relevance of support and encouragement for competency of this type in time of startup evaluation. With this objective in mind, we stated the following research objectives: 1) develop the integrated model (for the evaluation of innovation projects) that would include a qualitative criteria framework for application selection in business incubators, 2) as applied to applications and startups in existing business incubators, pilot the developed assessment model and compare piloting results with the ratings that such applications and startups received under the valid approach approved by business incubators.

\section{Literature review}

Innovation facilities play a key role in expansion of entrepreneurship projects. Establishment of accelerators, technological parks, and business incubators require substantial investments (Smirnov, 2017). With due consideration to resource mobilization, it becomes a priority to understand whether the establishment of such facilities is cost-effective (Rodionov, Tsypkin, \& Sinelnikova, 2012; Guidelines: Metrics...2013; Balashova \& Alekseev, 2018).

High-quality selection of prospective incubatees is not only an important practice-oriented, but also a theoretical objective. There is close attention that general public pays to this issue, but there is still not enough conceptualization in this field of economic relations. The entrepreneurship theory needs the elaboration of its framework knowledge about the entrepreneurship phenomenon including its categorical framework. It is a basic assumption that entrepreneurship is a purely practice-oriented issue, whereas it would be more appropriate to treat it as an essential component of economics as a science. Therefore, the development of the project evaluation framework should be in terms of modern development of economics as a science at the level of concepts and 


\section{ENTREPRENEURSHIP AND SUSTAINABILITY ISSUES}

ISSN 2345-0282 (online) http://jssidoi.org/jesi/

2020 Volume 7 Number 4 (June)

http://doi.org/10.9770/jesi.2020.7.4(27)

categories. I.e., we should take into consideration the achievements of cognitive science, including psychology based on the interdisciplinary approach to the methodology of academic sophistication.

There are numerous research papers on methods and models to evaluate business incubator performance. However, there is no common approach or list of criteria for such evaluation (Theodorakopoulos, Kakabdse, \& McGowan, 2014; Torun, Peconick, Sobreiro, Kimura, \& Pique, 2018). Transformation of approaches to evaluation of business incubator performance took place together with the development of business incubators themselves. If incubators of the $1^{\text {st }}$ generation (1980-1990) looked like office space, the $2^{\text {nd }}$ generation incubators (1991-2000) provided their residents with coaching and training sessions (Bruneel, Ratinho, Clarysse, \& Groen, 2012; Mian, Lamine, \& Fayoll, 2016). Finally, the $3^{\text {rd }}$ generation incubators of nowadays are facilities, a primary competitive advantage of which is an expanded range of services that they provide together with networking opportunities (Theodorakopoulos, Kakabdse \& McGowan, 2014; Bruneel, Ratinho, Clarysse, \& Groen, 2012; Mian, Lamine, \& Fayoll, 2016; Messenghem, Bakkali, Sammut, \& Swalhi, 2017).

Some researchers are skeptical about the very idea of the common approach to evaluation of business incubator performance. They think that successful incubators are not similar, and it is impossible to find a one-fits-all formula to measure success of the business incubators that belong to different types (Theodorakopoulos, Kakabdse, \& McGowan, 2014). On the other hand, results of the overview of numerous research on the development of approaches to performance evaluation of business incubator assume that there are several criteria that are regularly in use and recognized by everyone as indicators of the business incubator success (Theodorakopoulos, Kakabdse, \& McGowan, 2014; Torun, Peconick, Sobreiro, Kimura, \& Pique, 2018). Note that the list of success indicators is diverse. It includes the criteria that refer to incubator performance (number of incubatees, number of the applications processed annually, floor space, average number of the events held a year) and the criteria that refer to projects of business incubator residents (resident's survival rates, average incubation time, average number of jobs created by incubatee). Thus, business incubator performance also depends on its incubatees' success. Consequently, organizations that support startups should be extremely interested in successful development of their projects. It is possible to distinguish between several types of the well-accepted approaches: financial, multi-criteria, comparative (to compare projects with each other) and project portfolio approach (Shtefan \& Elizarova, 2018; Grekul, Isaev, Korovkina, \& Lisenkova, 2019).

Internationally, business incubators think that strict selection of applications is a condition of a project success as the strictness of the approach is directly proportional to the quality of the projects that will become incubatees. For example, in Europe, in 2012, the Central-European innovation center selected 28 startups out of 263 applications. In other words, it only accepted 9 percent of applications. For Russia-based business incubators, the same indicator is 37 percent (business incubators selected 363 startups out of 974 applications). At the same time, there are several most successful business incubators that are standout as their conversion rate is almost at the European level of 11 percent (Challenges and Solutions... 2013). In other words, Russian business incubators are not strict enough in project evaluation. Russian researchers have already discussed this issue. They have mentioned that the key weakness in existing approaches to project evaluation is that the projects with a priori poor chances for commercialization success can become incubatees (Yashin \& Kovrizhin, 2013; Dytynenko, Chudinov, \& Rojko, 2013). In the course of time, the approaches to project selection applied by business incubators to applications have remained unchanged. As before, a business plan quality is a primary selection criterion. At the same time, requirements to the business plan are vague and general. Suggesting the ways for improvement of the project selection approach, researchers focus on changes to the selection procedure (Yashin \& Kovrizhin, 2013; Tsukerman \& Shestakov, 2001).

Financial indicators of the project success usually serve as primary criteria for selection of innovation projects. However, this approach ignores relevant aspects of enterprise activities, e.g. product development, innovativeness, strategy, establishment of long-term customer relations. Stefan and Elizarova (2018) also point 


\section{ENTREPRENEURSHIP AND SUSTAINABILITY ISSUES}

ISSN 2345-0282 (online) http://jssidoi.org/jesi/

2020 Volume 7 Number 4 (June)

http://doi.org/10.9770/jesi.2020.7.4(27)

out that it makes sense to include qualitative indicators in the list of evaluation criteria. Their integrated evaluation model includes three criteria of public significance: share of costs for innovations, establishment of social programs for project implementation, need in new staff (Stefan \& Elizarova, 2018).

A key challenge associated with project selection at facilities of the innovation infrastructure is the lack of reliable data, as business plans of applicants often and beyond measure include optimistic values (Wachira, Ngugi, \& Otieno, 2017). Keeping this in mind, some researchers have proposed the hypothesis that the success of an innovation-based project not in the last place depends on entrepreneur's personality traits. For instance, Civarella et al. (2004) identified a positive correlation between entrepreneur's personal integrity and long-term project survival. Other personality traits had either negative correlations in terms of the project survival rate or made no significant influence on it at all.

Later researchers found that business incubators tend to paying more attention to personalities of entrepreneurs in addition to the projects themselves. Having analyzed the approaches to project selection criteria applied by 16 Sweden-based business incubators, Bergek and Norrman (2008) identified two approaches to the evaluation procedure of applications: project idea-focused selection approach and entrepreneur-focused approach. Undoubtedly, an advantage of mentioned approaches to application selection is that they make it possible to identify both quantitative and qualitative characteristics of a project and take into account an existing level of uncertainty in terms of the project commercial success (Grekul, Isaev, Korovkina, \& Lisenkova, 2019).

Now the application of the multi-factor evaluation to startup selection for business incubator residency is limited as there is no ready-made toolkit that would make it possible to have an integrated and automated evaluation of promising projects with measured indicators (Wulung, Takahashi, \& Morikawa, 2014). Stakeholders have already tried to develop the toolkit. For instance, Wulung, Takahahi and Morikawa (2014) offered the multi-objective selection model for evaluation of innovation project. The model combines evaluation of technical strengths of a project and individual personality traits of an applicant (entrepreneur).

Nevertheless, the overview of cases has shown that for project evaluation there are mainly models in use that lie on formal criteria, primarily, financial indicators. At the same time, at the initial stage, the startup owner's personality is of the primary importance. That is why making a longer list of selection criteria for innovation projects is crucial in terms of improvements as applied to the project selection procedure at business incubators and other facilities of the innovation infrastructure.

\section{Material and Methods}

The existing framework of evaluation criteria and ratings used for selection of innovation-based projects at business incubators and other facilities of the innovation infrastructure requires qualitatively new approaches. In this paper, we will present the method, which we developed as a scoring tool for startup evaluation, called the Management of Developing Projects (MDP).

The MDP method is a framework of qualitative and quantitative indicators considering personality types (psychotypes) of main economic entities. The method developed aims at better evaluation, development and support to business of those who participate in the innovation infrastructure. We believe that the MDP method is set to become a cross-functional tool that facilitate the successful growth of investment and innovation-based projects. The multi-criteria MDP method will make it possible to evaluate projects with due consideration to particular goals of innovation infrastructure facilities. It will also be a flexible tool for an analysis of startup capacity (in terms of acceptable risk policy). The MDP method is an important component in the methodology of developing project management and serves for initial evaluation of business incubatees and other facilities of the innovation infrastructure, as well as their further monitoring (see Fig. 1 below). 


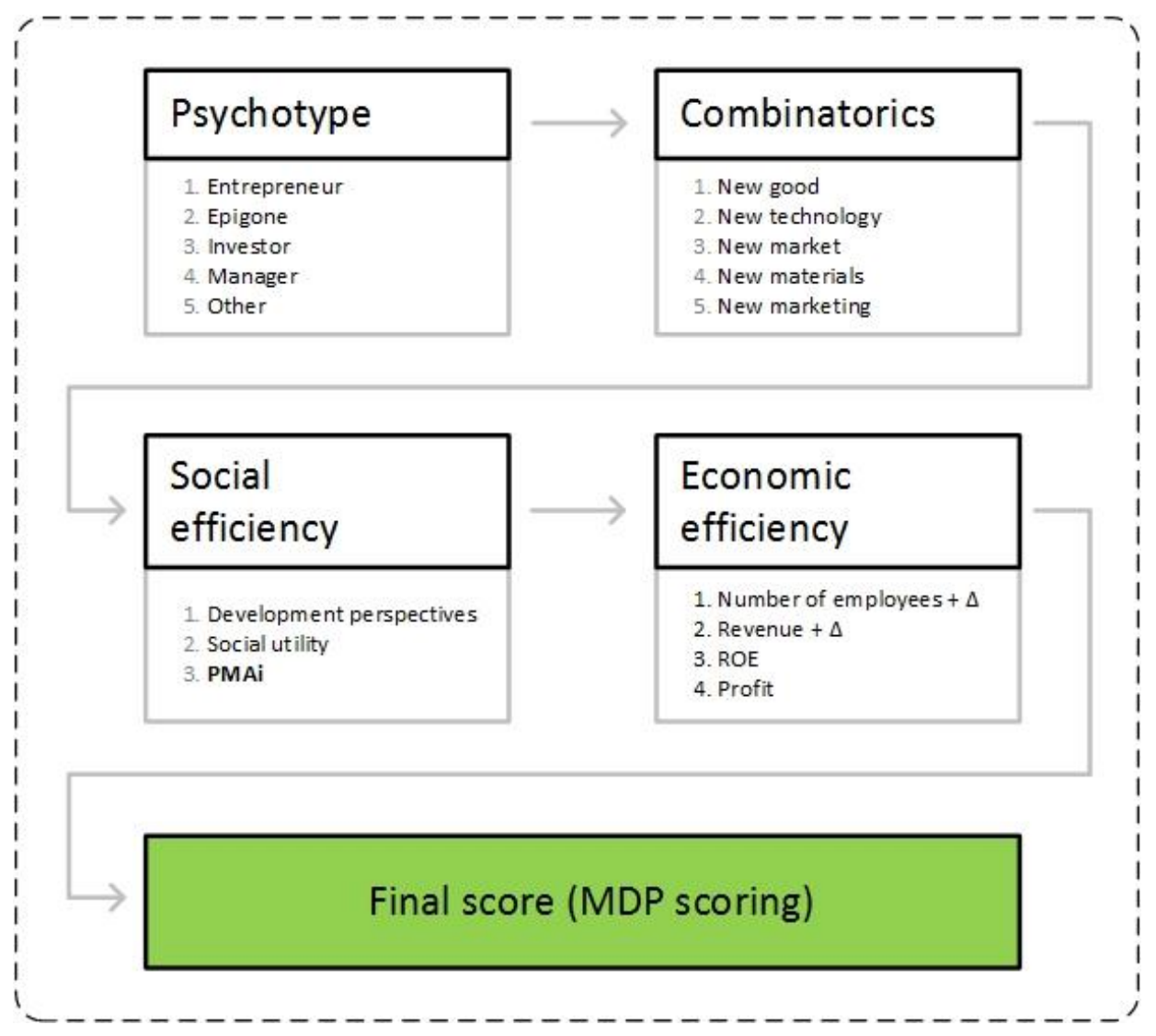

Fig. 1. The MDP method for innovation project evaluation

Economic Efficiency section includes quantitative evaluation components. Sections Social Efficiency, Psychotype (Personality Type) and Combinatorics include qualitative components of the evaluation. See more details on these components below.

\subsection{Psychotype. Definition}

Particular business entities are not equally significant for facilities in the innovation infrastructure. Therefore, it makes sense to classify main economic entities as market participants in accordance with their goal-setting specifics. For the purposes of the current research, it would be the most appropriate to distinguish between main personality types (psychotypes) of business actors (Litau, 2019).

Innovating entrepreneur. The person with a corresponding talent and capability that differ from the capabilities typical in logics, linguistics, and for other types of genius. Innovating entrepreneurs are committed to their ideas as they make their dreams true. As far as they get closer to the implementation, their dreams turn into objectives.

Manager. The qualified manager with measurable performance. As a rule, managers apply the systematic approach. They would rather avoid deciding in terms of total uncertainty and tend to adhere to the hierarchy of corporate values. The career advancement is their ultimate goal. 


\section{ENTREPRENEURSHIP AND SUSTAINABILITY ISSUES}

ISSN 2345-0282 (online) http://jssidoi.org/jesi/

2020 Volume 7 Number 4 (June)

http://doi.org/10.9770/jesi.2020.7.4(27)

Investor. This type differs from Entrepreneur and Manager by fundamentally different goals, as profitability is his/her main interest. He/she is neither interested in a project idea, nor project implementation in terms or management. An investor's goal is to make maximum return on investment.

Epigone. Epigonism means an inclination to copying of someone else's ideas and following general trends. Epigones take an intermediary position between personality types of Manager and Entrepreneur. They are ready to take some risk and interested in idea implementation. They also want to be directly involved in project management. Epigones do not destroy established stereotypes, they prefer mainstreaming and benefit from proven investment opportunities only.

We used the idealization technique as a scientific method of inquiry, i. e. exaggeration of those traits that refer to the manifestation of basic specific properties of personality types, in order to identify their distinctive features in the clear and convincing way. Identification of qualitative characteristics of each of the presented personality types will make it possible to specify the creative component, so important for today's economy (classification of main economic entities creates wide opportunities for the development of tailored educational programs to train professionals, which is an urgent need in the current system of education. In spite of the high demand for entrepreneurship, in management training there is no due consideration given to personal inclinations to specific types of management. The lack of the differentiated approach to education and support inevitably leads to a poor quality of innovation-based entrepreneurial projects).

\subsection{Combinatorics}

The criteria covered in the Combinatorics section of the scoring tool make it possible to rank projects by innovation type in compliance with the PMAi model (Progressive Materialization of Anti-idea) and evaluate the novelty of a project idea.

The PMAi model serves as a basis for understanding of an innovation project relevance. This can be in use for further development of a set of criteria to evaluate a scale and utility in terms of prospective implementation of entrepreneurial creativity.

\subsection{Economic efficiency}

The MDP method assumes the following economic efficiency criteria:

Relative dynamics of staff number. The growing staff number is one of the main project indicators of a company's growth (Litau, 2013). Absolute values will be less indicative as they are sector-specific.

Relative dynamics of revenue. At the stage of project development, the revenue is the most appropriate criterion of the project progress compared to the profit for a number of reasons. Modern projects follow another development path as compared to a traditional one. The profit is no longer obligatory for project success. Startups grows at the cost of a value increase of equity instruments without any commercial justification in terms of the profit and classical financial analysis. The incremental loss is no longer an exclusively negative factor, as it is typical for the initial stage in the project development. In view of the above mentioned, ROE and ROI have the least weight as they directly correlate with the profit, and no profit does not mean no commercial potential of a project.

\subsection{Social efficiency}

Efficiency is ranked by social benefit. An existing good is destroyed as far as a new idea is implemented. This launches the economic development process. Therefore, we assume that the new good bears the benefit. 


\section{ENTREPRENEURSHIP AND SUSTAINABILITY ISSUES}

ISSN 2345-0282 (online) http://jssidoi.org/jesi/

2020 Volume 7 Number 4 (June)

http://doi.org/10.9770/jesi.2020.7.4(27)

Ranking by scores goes from the evaluation of a project impact's scale on the market (above all, by distribution of the new product or service, i.e. sales level). We follow the Likert scale with 1-7 scale points as the best tool (Preston \& Coleman, 2000).

\subsection{Piloting of the MDP method}

We piloted the MDP method in January-February 2020 using project applications submitted to business incubators in Saint Petersburg (Russia). In compliance with objectives of our research, we limited ourselves to those facilities of the innovation infrastructure that select residents by competitions. We collected primary data from 12 in-depth interviews and the questionnaire-based survey. An aim of interviewing was to identify the relevant managerial skills that are typical for each of the described psychological types and that influence their business practices.

Heads of business incubators gave us lists of the projects proposed by applicants and incubatees, on which we piloted the scoring tool.

We selected the projects using the following criteria as applied to responding initiators of projects:

1. Age: 21-40. At this age, inclination to entrepreneurship should manifest itself. At the same time, people of this age are still flexible.

2. Gender was irrelevant for the research.

3. Prior business experience of at least 3 years. We assume that for three years of business experience a person developed main thinking patterns typical for implementation of the economic activity and that are subject to observation.

The first piloting stage included preliminary tests of the questionnaire in order to: 1) identify concepts and fixed phrases with meanings ambiguously perceived by respondents, 2) evaluate respondents' perceptions in terms of to what extent concepts and questions differ from those definitions that serve as a theoretical basis of the research, 3) identify the questions that do not mirror the research objectives or significantly deviate from them, 4) identify the questions that are the best for measurements of respondents' attitudes and behavior patterns, 5) group respondents' answers by question wording.

Cognitive interviews took place with participants (incubatees) of a business incubator. Respondents varied by age, education level, prior business experience, and duration of their participation in a program of their business incubator. Based on results of interviewing, we revised wordings of several questions in the questionnaire and prepared the questionnaire for the next stage of piloting.

For the second piloting stage of the MDP method, we used the list of projects provided by business incubators Politekh and Ingria, and selected 17 projects for another survey round using the revised questionnaire. We processed the collected data and got integrated scores per project.

\section{Results and Discussion}

First Russia-based technological parks appeared in early 1990-ies. The year of 2006 was a start of a rapid growth in numbers of technological parks and business incubators, as well as other facilities of the innovation infrastructure. Since 2012, we have observed certain stagnation, "technological park development was inconsistent and episodic, with points of the strong growth followed by decline (Fourth annual overview ...2018). 


\section{ENTREPRENEURSHIP AND SUSTAINABILITY ISSUES}

ISSN 2345-0282 (online) http://jssidoi.org/jesi/

2020 Volume 7 Number 4 (June)

http://doi.org/10.9770/jesi.2020.7.4(27)

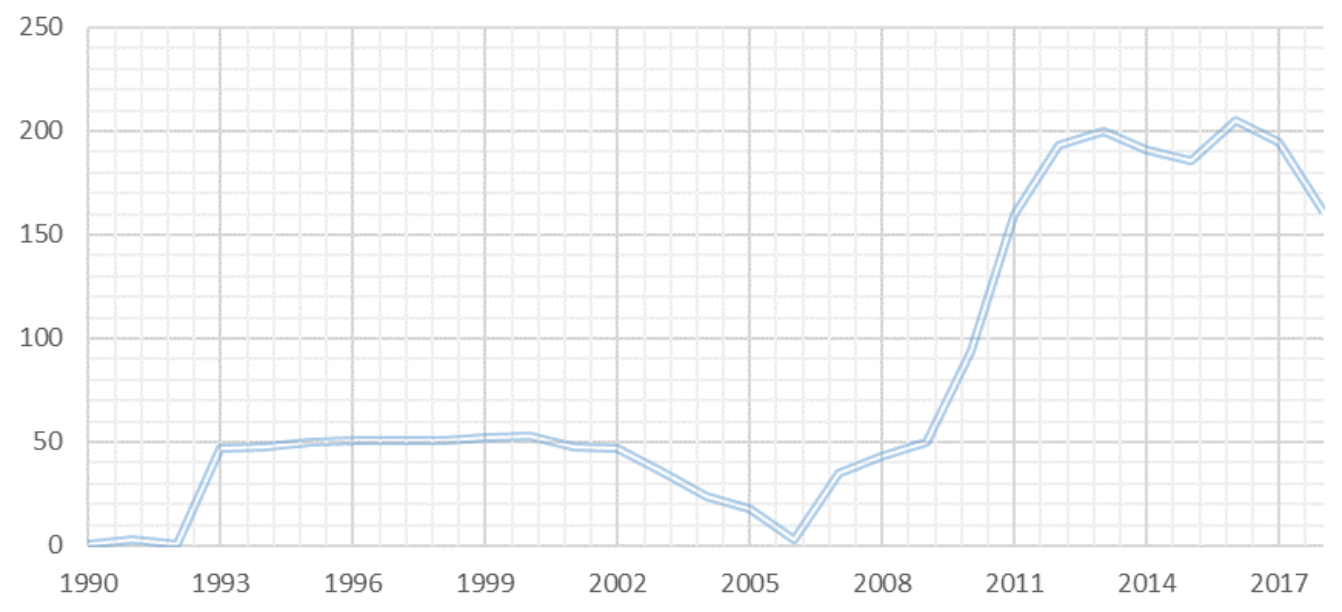

Fig. 2. Incorporation dynamics of Russia-based technological parks in 1990-2018

Source: Technological parks of Russia-2018.' Fourth annual overview

The clear decline in activities of innovation infrastructure facilities (Fig. 2) inevitably resulted in serious narrowing of the sample. However, having talked to heads of innovation infrastructure facilities, we concluded that the observed decline was due to principles in functioning of these facilities, rather than the overall economic situation. In some cases, (for example, ITMO University business incubator), respondents mentioned that a university was fundamentally not a proper place for establishment of business entities. In other cases, respondents referred to administrative constraints as a reason for poor performance of business incubators. For instance, government funding (which prevail in the innovation infrastructure) of innovation-based startups had been paralyzed as these are the projects with high commercialization uncertainty. Thus, there is a need in a new focus on the work system of the facilities that support and develop startups.

According to Expert Online, the innovation infrastructure of Saint Petersburg consists of various types of facilities: business incubator, technological park, science city, "Special Economic Zones" managing company, nanotechnology-based center, resource sharing center, engineering center, prototyping and technology transfer center, and innovation and technology center. Thus, the innovation infrastructure of Saint Petersburg and the Leningradskaya Oblast includes 34 facilities that include 9 technological parks ( 7 in Saint Petersburg and 2 in the Leningradskaya Oblast).

In 2016, three business incubators from Saint Petersburg were on the list of top innovation-based programs under three categories: university-based business incubators (the ITMO University business incubator), the business incubators with university affiliation (Ingria business incubator), and university-based accelerators (iDealMachine, ITMO University).

So far, iDealMachine accelerator has stopped operations.

Ingria business incubator provides startups with development support. It was established in 2008. Evaluating and inspecting of business ideas and projects is a core component in its activities.

Politekh center for development of technology projects and entrepreneurship was launched in 2011 to support techpreneurs to turn their innovation ideas in functioning production facilities.

Having applied the MDP scoring method, we found that the numbers of promising projects (as defined by the MDP method, on the one hand, and Politekh and Ingria business incubators, on the other hand) were substantially different. 
The application of the MDP method shown that out of 17 evaluated projects only 9 are promising, whereas business incubators thought that 14 projects meet the eligibility criteria for business incubator residence. Besides, 9 selected startups included 3 projects that do not meet the incubator eligibility criteria, but that are promisingly successful in terms of the MDP. Finally, in spite of a significant decrease in numbers of promising projects as calculated by the MDP method, we identified that 3 promising projects had not been selected by quantitative criteria but had been the most interesting in terms of qualitative criteria.

The questionnaire-based survey showed that 9 selected projects ( 47 percent) were launched by Epigones with the entrepreneurial component and are promisingly interesting in terms of further entrepreneurial education and training (Fig. 3). Project distribution by criteria from the Combinatorics section demonstrated that the prevailing number of projects (62 percent) involve the application of novel materials (Fig. 4).
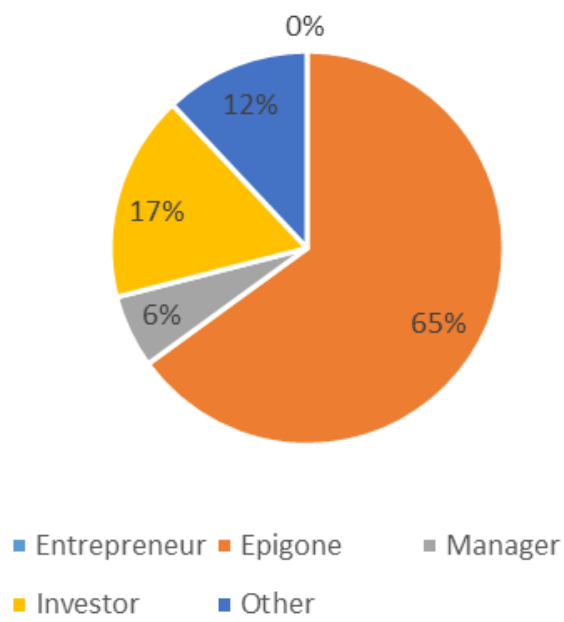

Fig. 3. Distribution of projects by initiator's psychotype
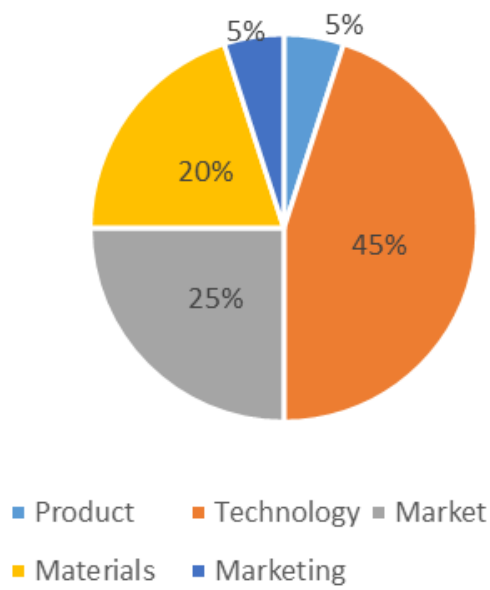

Fig.4. Distribution of projects by Combinatorics criteria

Fig. 5 shows that projects mostly have the trend line showing a link between cost-effectiveness and social benefit of projects. Only three projects out of 17 demonstrate significant economic indicators together with low scores for the social benefit and as low final score in Combinatorics section.

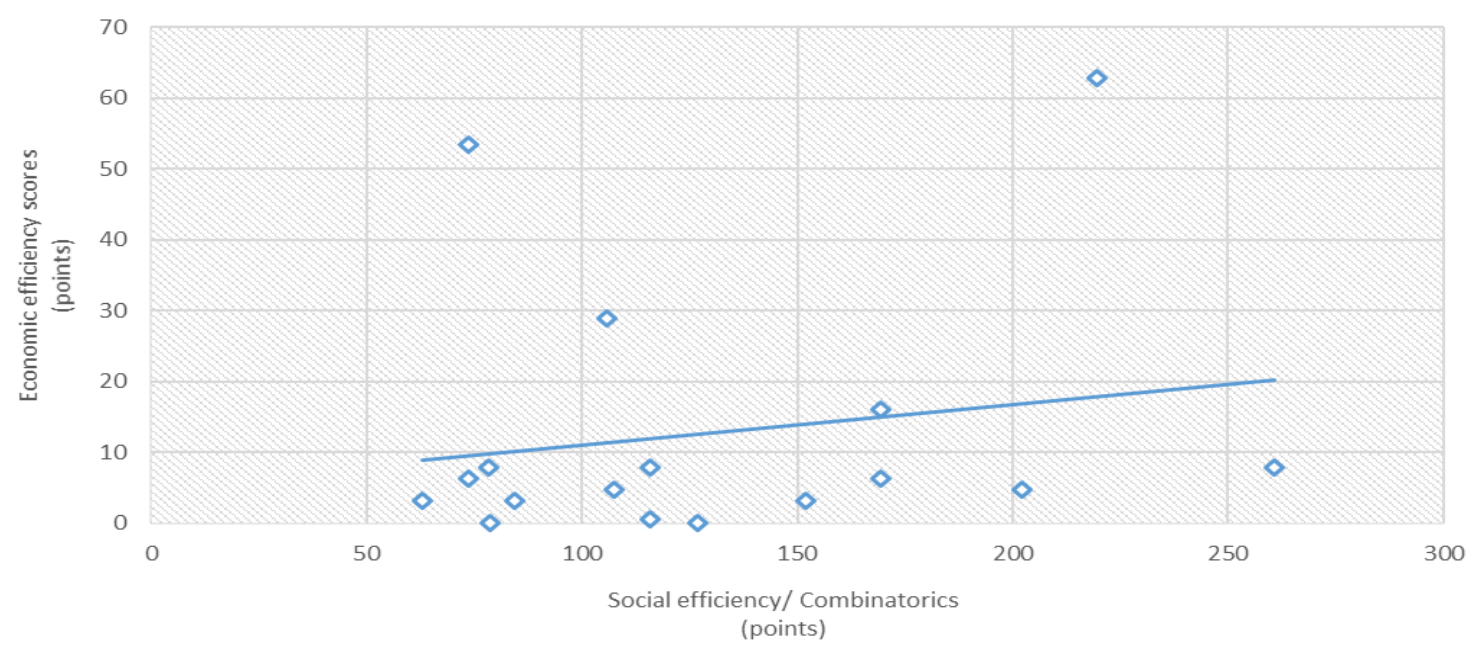

Fig. 5. Estimated distribution corridor of respondents 
Final ranking of projects shows that projects No. 1, 7 and 10 have received highest MDP scores and are the most promising in terms of business development (Fig. 6).

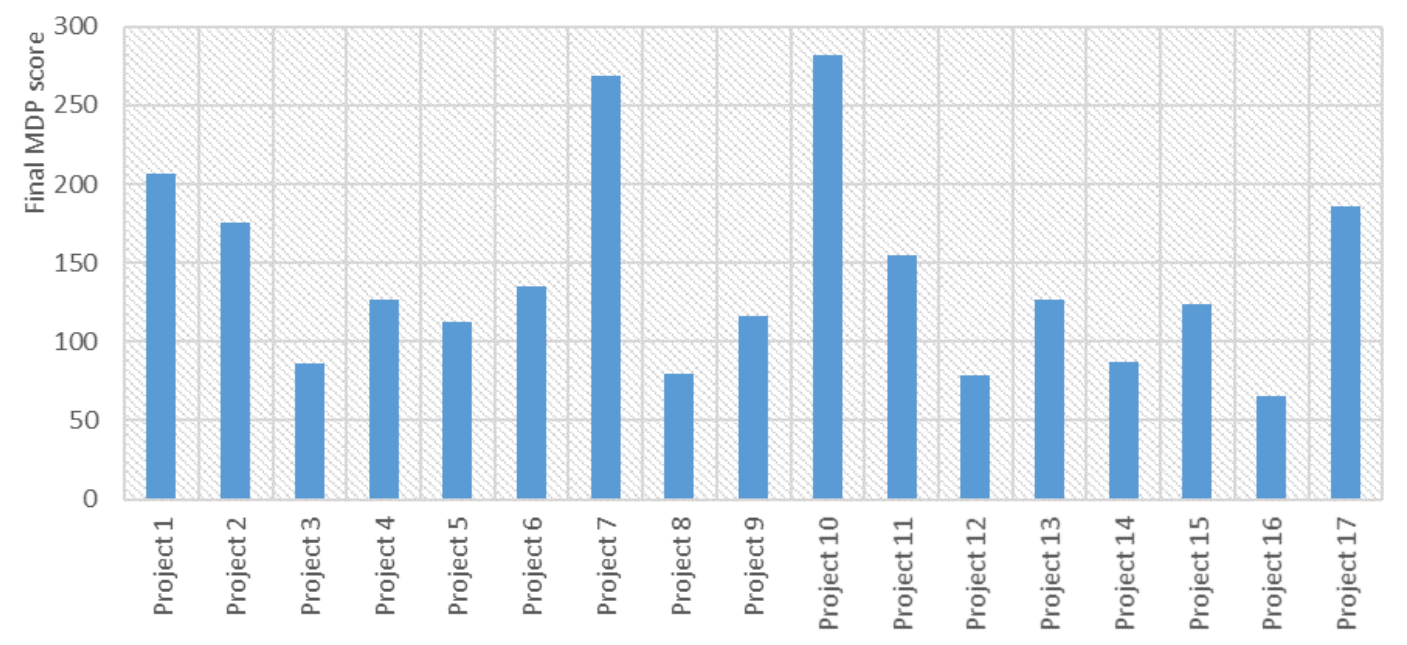

Fig. 6. Ranking of projects based on their final MDP scores

The model building principle, which is the basis of the MDP method, makes it possible to apply it to innovation infrastructure facilities with due consideration to their individual goals. For instance, the research showed that a number of entities including sector specific governmental agencies, in practice do not support projects with the innovative component due to their high investment risk. However, these projects are of greater interest in view of a particular group of investors. Moreover, initiators of projects from this group are the most promising in terms of development of their entrepreneurial skills in innovation-based project management. Consequently, exchange of such data between stakeholders can significantly increase their performance and create synergy between universities, private companies and governmental agencies that support the development of entrepreneurial initiatives.

\section{Conclusions}

The method we developed was successfully piloted at two prominent business incubators of St. Petersburg (Russia). Piloting of the MDP multi-criteria scoring method approbation clearly showed that the application of qualitative criteria essentially broadens opportunities of experts at business incubators when they decide on projects using the available information. Moreover, the MDP method makes it possible to evaluate projects considering individual goals of business incubators, i.e. go beyond the economic parameters (which are often not satisfactory but normal for project specifics) and take into account the personality types of their initiators as they play a key role in the future success of projects. This is to be necessarily considered in the approach to startup selection.

The important outcome from the MDP method application is that in further monitoring of the most successful projects, it will be possible to specify managerial skills of startup initiators based on their psychological types, which consequently will make it possible to develop university-based educational programs that will meet the market demand. 


\section{ENTREPRENEURSHIP AND SUSTAINABILITY ISSUES}

ISSN 2345-0282 (online) http://jssidoi.org/jesi/

2020 Volume 7 Number 4 (June)

http://doi.org/10.9770/jesi.2020.7.4(27)

\section{References}

Balashova, K.V. \& Alekseev, A.L. (2018). Instrumentary expert evaluation of innovation projects and technologies. Radio industry (Russia), 2, 99-104. https://doi.org/10.21778/2413-9599-2018-2-99-10

Baron, R. A. (2008). The Role of Affect in the Entrepreneurial Process. Academy of Management Review. 33(2), 328-340. https://doi.org/10.5465/amr.2008.31193166

Batkovskiy, A. M., Nesterov, V. A., Semenova, E. G., Sudakov, V. A., \& Fomina, A. V. (2017). Developing intelligent decision support systems in multi-criteria problems of administrative-territorial formations infrastructure projects assessment. Journal of Applied Economic Sciences, 12(5), 1301-1311.

Baum, J. R. \& Bird B.J. (2010). The successful intelligence of high-growth entrepreneurs: Links to new venture growth. Organization Science, 21(2), 311-591. https://doi.org/10.1287/orsc.1090.0445

Beatty, P.C. \& Willis G.B. (2007). The practice of cognitive interviewing. The Public Opinion Quarterly, 71(2), 287-311. https://doi.org/10.1093/poq/nfm006

Bergek, A., \& Norrman, C. (2008). Incubator best practice: A framework. Technovation, 28(1-2), 20-28. https://doi.org/10.1016/j.technovation.2007.07.008

Birch, D. \& Medoff, J. (1994). Gazelles. In Solomon L., Levenson A. (Eds.) Labor markets, employment policy and job creation. Boulder, CO: Westview Press (pp. 159-167). https://doi.org/10.4324/9780429046834-7

Birch, D. L. (1987). Job creation in America: How our smallest companies put the most people to work. Free Press, New York.

Bruneel, J., Ratinho T., Clarysse B., \& Groen A. (2012). The evolution of business incubators: Comparing demand and supply of business incubation services across different incubator generations. Technovation, 32(2), 110-121. https://doi.org/10.1016/j.technovation.2011.11.003

Campanelli, P. (1997). Testing survey questions: New directions in cognitive interviewing. BMS: Bulletin of Sociological Methodology, 55, 5-17. https://doi.org/10.1177/075910639705500103

Castillo-Díaz, M., \& Padilla, J.-L. (2012). How Cognitive Interviewing can Provide Validity Evidence of the Response Processes to Scale Items. Social Indicators Research, 114(3), 963-975. https://doi.org/10.1007/s11205-012-0184-8

Chernova, V., Degtereva, E., \& Zobov, A. (2016). Scientific-Industrial and Economic Cooperation Between Russia and BRICS States: Proposal of Effective Forms and Mechanism. Journal of Comparative Asian Development, 15(3), 333-360. https://doi.org/10.1080/15339114.2016.1249896

Civarella, M.A., Buckholtz, A.K., Riordan, C.M., Gatewood, R.D., \& Stokes, G.S. (2004). The big five and venture survival: is there a linkage? Journal of Business Venture, 19, 465-483. https://doi.org/10.1016/j.jbusvent.2003.03.001

Dellis, K., Karkalakos, S., \& Kottaridi, C. (2016). Entrepreneurship Targeting Policies, Technological Growth, and Unemployment. Journal of Eurasian Economic Dialogue, 1(6), 19-39.

Devyatko, I.F. \& Lebedev, D.V. (2017). Through the eyes of the interviewer, through the eyes of the respondent: Outlining new approach to the assessment of cognitive load when conducting a survey. Public opinion monitoring: Economic and social changes, 5(141), 1-19. https://doi.org/10.14515/monitoring.2017.5.01

Dimov, A. (2007). Beyond the single-person, single-insight Attribution in understanding entrepreneurial opportunity. Entrepreneurship Theory and Practice, 31(4), 561-583. https://doi.org/10.1111/j.1540-6520.2007.00188.x

Dytynenko, P.N., Chudinov, S.M., \& Rojko, G.A. (2013). Information support of the selection of innovation projects. Nauchnye Vedomosti, 15(158), 179-185.

Fourth annual overview 'Techonological parks of Russia -2018' (2018). Association of clusters and technoparks of Russia. Moscow, AKIT RF. 


\section{ENTREPRENEURSHIP AND SUSTAINABILITY ISSUES}

ISSN 2345-0282 (online) http://jssidoi.org/jesi/

2020 Volume 7 Number 4 (June)

http://doi.org/10.9770/jesi.2020.7.4(27)

Grekul, V.I., Isaev, E.A., Korovkina, N.L., \& Lisenkova, T.S. (2019). Developing an approach to ranking innovative IT projects. Business Informatics, 13(2), 43-58. https://doi.org/10.17323/1998-0663.2019.2.43.58

Guidelines: metrics \& milestones for successful incubator development. A white paper. (2013). Retrieved from: https://assets.aspeninstitute.org/content/uploads/files/content/docs/resources/A\%20White\%20Paper_Metrics\%20\%20Milestones\%20for\% 20Incubators.pdf

ITMO close the business-incubator (2017). Deloboy Peterburg. Retrieved from https://www.dp.ru/a/2017/12/04/ITMO_zakrivaet_biznes$\underline{\text { ink }}$

Lambert, T. E. (2018). Monopoly Capital and Innovation: an Exploratory Assessment of R\&D Effectiveness. Journal of Eurasian Economic Dialogue, 3(6), 20-35.

Litau, E. (2013). Theoretical and methodological approaches in the area of small developing enterprise management. Synopsis of the thesis. St. Petersburg.

Litau, E. (2017). 'Evolution of species' in business: From mice to elephants. The question of small enterprise development. Journal of Advanced Research in Law and Economics, 8(6), 1812-1824. https://doi.org/10.14505/jarle.v8.6(28).16

Litau, E. (2019). Classification of economic psychotypes subjects management. Economic Science and Humantities, 2(235), 100-110.

Messenghem, K., Bakkali C., Sammut S., \& and Swalhi A. (2017). Measuring nonprofit incubator performance: Toward an adapted balanced scored approach. Journal of Small Business Management, 56(10). https://doi.org/10.1111/jsbm.12317

Mian, S., Lamine, W. \& Fayoll, A. (2016). Technology business incubation: An overview of the state of knowledge. Technovation, 5051(1), 1-12. https://doi.org/10.1016/j.technovation.2016.02.005

Molina, J. A., Velilla, J., \& Ortega, R. (2016). Entrepreneurial Activity in the OECD: Pooled and Cross-Country Evidence. Journal of Eurasian Economic Dialogue, 1(6), 1-18.

Organizations of innovation infrastructure of St. Petersburg (2020). Expert Online. Retrieved from: https://expert.ru/ratings/organizatsiiinnovatsionnoj-infrastrukturyi/

Oslo Manual: guidelines for collecting and interpreting innovation data (2010). Organization for Economic Cooperation and Development and Eurostat. Moscow. Retrieved from: https://mgimo.ru/upload/docs 6/ruk.oslo.pdf

Preston, C. \& Colman, A. (2000). Optimal number of response categories inr scales: Reliability, validity, discriminating power, and respondent preferences. Acta Psychologica, 104, 1-15. https://doi.org/10.1016/S0001-6918(99)00050-5

Rodionov, D., Tsypkin, Y., \& Sinelnikova, S. (2012). Performance of technoparks and business-incubators. St. Petersburg State Polytechnical University Journal. Economics, 4(151), 150-159.

Rogozin, D. (2002). Cognitive analysis of survey questionnaire. Dissertation. Retrieved from: http://cheloveknauka.com/v/59543/d\#?page=1

Shtefan, M.A. \& Elizarova, J.M. (2018) Investment project efficiency and risk evaluation: an integrated approach. Business Informatics, 4(46), 54-65. https://doi.org/10.17323/1998-0663.2018.4.54.65

Smirnov, R.O. (2017). Issues of commercialization of innovative technologies in the Russian Federation in the field of entrepreneurial activities. Radio industry (Russia), 3, 110-112. https://doi.org/10.21778/2413-9599-2017-3-110-112

Theodorakopoulos, N., Kakabdse, N., \& McGowan, C. (2014). What matters in business incubation? A literature review and suggestion for situated theorising. Journal of Small Business and Enterprise Development, 21(4), 602-622. https://doi.org/10.1108/JSBED-09-2014$\underline{0152}$

Toomsalu, L., Tolmacheva, S., Vlasov, A., \& Chernova, V. (2019). Determinants of innovations in small and medium enterprises: A European and international experience. Terra Economicus, 17(2), 112-123. https://doi.org/10.23683/2073-6606-2019-17-2-112-123

Torun, M., Peconick, L., Sobreiro, V., Kimura, H., \& Pique, J. (2018). Assessing business incubation: A review on benchmarking. International Journal of Innovation Studies, 2(3), 91-100. https://doi.org/10.1016/j.ijis.2018.08.002 


\section{ENTREPRENEURSHIP AND SUSTAINABILITY ISSUES}

ISSN 2345-0282 (online) http://jssidoi.org/jesi/

2020 Volume 7 Number 4 (June)

http://doi.org/10.9770/jesi.2020.7.4(27)

Tsukerman, V.A. \& Shestakov, A.A. (2001). Methods of classification and selection of projects: a vague approach. Mining informational and analytical bulletin, (3), 222-226.

Wachira, K., Ngugi P., \& Otieno R.O. (2017). Incubatee selection criteria and its role on entrepreneurship growth: A survey of university based business incubators in Kenya. International Journal of Academic Research in Business and Social Sciences, 7, 28-38. https://doi.org/10.6007/IJARBSS/v7-i1/2553

Wulung, R. B. S., Takahashi, K., \& Morikawa, K. (2014). An interactive multi-objective incubatee selection model incorporating incubator manager orientation. Operational Research, 14(3), 409-438. https://doi.org/10.1007/s12351-014-0148-7

Yashin, S.N \& Kovrizhin, Y.A. (2013). Improvement of the methodology of selection of residents in state business-incubators. Financial Analysis: Challenges and Solutions, 28(166), 13-22.

Ekaterina LITAU, PhD (Economics \& Management), M.Sc. (Finance \& Economics), J.D., associate professor, Faculty of Technological Management and Innovations, Saint Petersburg National Research University of Information Technologies, Mechanics and Optics (ITMO University). Ekaterina is an author of books on project management and initiator of entrepreneurial projects. She has done research on entrepreneurship for more than 15 years and is currently involved in interdisciplinary studies in the field that brings together economics, neuroentrepreneurship, and cognitive science. Her research interests include theory of entrepreneurship, neuroentrepreneurship, modern economic models, enterprise development, financial management, and cognitive science in economics.

ORCID ID: orcid.org/0000-0003-0045-8778

Register for an ORCID ID:

https://orcid.org/register

Copyright (C) 2020 by author(s) and VsI Entrepreneurship and Sustainability Center

This work is licensed under the Creative Commons Attribution International License (CC BY).

http://creativecommons.org/licenses/by/4.0/

cC) (7) Open Access 